\title{
The Effect of Market Anomalies on the Inefficiency of Stock Returns
}

\author{
Mehran Ansari ${ }^{1}$, Hojat Jafari ${ }^{2, *}$ \\ ${ }^{1}$ Faculty of Management and Accounting, Tehran University, Tehran, Iran \\ ${ }^{2}$ Abadan Faculty of Petroleum Engineering, Petroleum University of Technology, Abadan, Iran
}

Email address:

Hojatjafari80@yahoo.com (H. Jafari)

${ }^{*}$ Corresponding author

\section{To cite this article:}

Mehran Ansari, Hojat Jafari. The Effect of Market Anomalies on the Inefficiency of Stock Returns. American Journal of Theoretical and Applied Business. Vol. 6, No. 3, 2020, pp. 23-27. doi: 10.11648/j.ajtab.20200603.12

Received: July 2, 2020; Accepted: August 18, 2020; Published: September 16, 2020

\begin{abstract}
This paper serves the purpose to analyses market anomalies and their agents on returns in the Iranian indexes between 2017 and 2020. Principled patterns in financial market are incompatible to the efficient market hypothesis, as stock market returns can be done applying these systematic models. Real investors may not be able to achieve the return and profitability due to the scarcity of their financial resources. Accordingly, the study of the role of real investors in the volatility of stock returns is very important. Well timed actions of investors prices of stocks directly adapt to the new information, and give thought to all the available information. So no investor can chastise the market by generating abnormal returns. The model period is 2017 to 2020 to represent the continuity of the monthly result. This scholarship put upon the advantageous sampling procedure, also known as the judgmental sampling technique, of weekly returns from Iranian indexes and major world indexes based on specific criteria. The demodulations offer an abnormal month of the year outcome stand in some Iranian indexes during the research duration. The vehemence of month of the year anomalies lessens with time. The investigation also illustrate that month of the year factors are more unremitting between indexes with smaller market capitalization.
\end{abstract}

Keywords: Real Investors, Month of the Year Effect, Return, Market Anomalies

\section{Introduction}

Principled patterns in financial market are incompatible to the efficient market hypothesis (EMH), as stock market returns can be done applying these systematic models [1-30]. These patterns efficacy the efficiency of stock market being about market anomalies [30-43]. Between these systematic patterns, one of the widepropagation anomalies is month effect. Pertaining data on the clause and orientation of a market will be achievable to financiers if the market is impressive [1-3]. Bhuyan (2018) and Chandra (2017) in his book discuss that an efficient market can demonstrate factual stock prices also avouch the validity of the circumstances illustrated. Investigation on the revenue of capital markets is mostly complete $[4,7]$. These studies discover the contrary of the notion of affective capital markets in some capital markets, that is when the state of the stock does not identity existing witting. Bodie et al. (2012) in their wittings arranged three cliques of market efficiency based on data containing weak form proficiency, semi-strong form proficiency and permanent form proficiency [5]. A disputation of efficient market examination cannot be separated from a disputation of the individuation of the perversions and burbles associated with the effectual market hypotheses. Deflections and disorderliness's are called market anomalies. Jiang and autore (2014) and onoh and ndu-okereke, (2016) express that different situations in a capital market will reason impacts that can be looked in the pulsation of stock prices in a capital market [22, 30]. Unpredictable status with instances or tentative outlooks in a capital market are also customarily named market irregularities. In other words, a market anomaly is a proof of an aberration or an antithesis in the capital market hypothesis. One likewise market irregularity is the month of the year effect. correspondent to Jahfer and Inoue (2014) the month of the year result mentions to the case whereby the stock returns in selected months are higher than in other months [21]. The most widepropagation and exciting 
demodulation from the above studies of the monthly result anomaly within a year. afterwards, a stock price may growth or diminution from month to month in one interchanging year in a capital market. This treatment is called the month of the year effect. The month of the year effect refers to the discrepancy in monthly returns in each month of the year. Specifically, this study objects to dissociation the phenomenon of a market's anomalous month of the year outcome on the indexes of Iran indexes.

\section{Research Methods}

A fund market is a pivotal mean in an economy that renders to outfit funds from citizens to plenteous parts. A company is an opponent that requisites sources and can enhance them through the capital market by marketing its shares to the public or exporting bonds. however, investors are an opponent with funds who can utilize the capital market as an another enterprise to attainment profits [31-36]. In his book indicates that the benefits of capital markets are that they supply fountainheads of financing for the business world plus allow the optimal allocation of fund inventions; impute vehicles to investors while enabling diversification musses; furnish outstanding indexes for the country's economic trends; administer company acquisition to the middle class; propagation acquisition, openness and profession; make a wholesome business climate; outreach employment or number of profession and render the chance to have a wholesome and futuristic company. Market output can be defined as the ratio between security prices and the data in course. A market is forenamed to be impressive if no one particular investor or institutional investor can gain uncommon returns, equiponderant for risk, using existing trading tactics (Wong et al., 2006; Zhang, Lai et al., 2017). Bodie et al. (2012) in his transpiration identifies three kinds of impressive market hypotheses relying on "all existing information". The feeble form hypothesis shows that stock prices erenow reverberate all the information that can be gained by testing market trading data such as a history of past prices, trading volume or short-term interest rates. The semi-strong form obligation develops the notion that all publicly accessible information regarding a company's panoramas should be inverted in stock prices. A safe form of the affective market express that stock prices reverberate all the relevant data on a company even containing information that is only available to people within the company (Clarke et al., 2008). A market anomaly is a rule less situation that is unsuitable or extravagates from an efficient market hypothesis. The anomaly here is one of the phenomena in the marketplace, where things are found that should not stand and it is supposed that efficient markets exist. Investors can obtain advantage of situation in the event of market anomalies to get abnormal returns on investments [42, 43]. Jamróz Pawełand Koronkiewicz (2014) Lopez Bernal et al. (2013) and Moskowitz et al. (2012) showed that an anomalous analysis is usually relyed on perceptions of long-term financial time series to study its effects and its repetition [23, 27, 28]. Long-term series must be important because they lower the likelihood of discovering relevant phenomena. An ongoing anomaly is a needful status to make a profitable enterprise strategy. Schwert (2003) ratiocinated that calendar anomalies are empirical outcomes that are repugnant with the demeanor theory of possession valuation [34]. This pretension is founded by Hawaldar et al. (2017) and Jain (2017) $[20,22]$. One of the anomalies that surfaced calendar month of the year is the result that is the mold in certain months of each year. Jahfer and Inoue (2014) indicate the most common demodulation about the study of the month of the year result are the "January effect" and the "April effect" [21]. It is well-thought-of that stock returns in January and April are main and variant from other months of the year yield. This infract the efficient market hypothesis (EMH) partly outstretched by Fama in the 1960s [15]. Sharpe et al. (1999) tongue there are three reasons of the January result, that is tax-loss selling, window dressing and small and beta stocks [35]. Tax-loss selling is selling stocks with a low value with the purpose of diminishing tax debt, while window dressing sells stocks with low value so the year-end portfolio of a company sight good. A small or beta stock is the tropism in January for more small companies to furnish a higher level of return contrasted to large companies. Bekaert and Hodrick, (2017) describe a return as the outcome gained from a finance [3]. The relapse may be for an investment that has happened or expectances that have not occurred yet but are attended to occurred in the days to come. The stock returns for each day can be accounted exploiting the addendum formula $[16,19$, 39]:

$$
R_{d}=\ln \frac{P_{d}}{P_{d-1}} \times 100
$$

Where $R_{d}$ is return of stock on day $d, P_{d}$ is the closing price on day $d$ and $P_{d-1}$ is the closing price on day $d-1$.

\subsection{Data Collection Method}

The information analysis contained of many steps, namely numerating each return from January 2017 to 2020 and then regimentation the computed return indexes into months. Moreover, a market dissociation examination eligible anomalous month of the year factors. In this test, the tester examining to analyse the entity of market anomalies about the month of the year result on some Iranian indexes and the world's major indexes pending the perception period, that is 2017 to 2020 . scholar in equivalent studies have used the linear regression test (OLS) and the Generalized Autoregressive Conditional Heteroskedasticity (GARCH) method.

\subsection{Simple Linear Regression Analysis}

Model was executed by gaining a dummy variable with the regression equation, as showed below: 
Where, $R_{m}$ is monthly return index in $\mathrm{t} ; \beta$ is regression coefficients for the dummy variable of each month except one; $D$ is dummy for each month except one. Hakim (2014) noticed that, to acquire an estimator with the hoped-for properties, or Best Linear Unbiased Estimator, OLS should meet standard guess. the linear regression model are as follows:
The Mean Residual $=\mathrm{E}\left(\mathrm{u}_{\mathrm{i}} \mid \mathrm{X}_{\mathrm{i}}\right)=0$,

Assumption's Homokedastisitas $=\mathrm{E}\left(\mathrm{U}_{\mathrm{i}} \mid \mathrm{X}_{\mathrm{i}}-\mathrm{E}\left(\mathrm{U}_{\mathrm{i}} \mid \mathrm{X}_{\mathrm{i}}\right)\right)^{2}=\sigma^{2}$

The Assumption of No Serial Correlation=E $\left(U_{i} \mid X_{i}-E\left(U_{i} \mid X_{i}\right)\right)\left(U_{j} \mid X_{j}-E\left(U_{j} \mid X_{j}\right)\right)=0,{ }_{i} \neq{ }_{j}$,

Since the researcher is exploit time series data, transgression variance cases were often set up that are not constant. Consequently, the time series data has a heteroscedasticity problem. Chatfield (2016), Fryzlewicz and Subba Rao (2014) argued that an error does not obtain a constant variance problem, but it can safely be applied for modelling and auguring $[8,18,29]$. The basic equation using ARCH modelling. In their work Nachrowi and Usman (2006) perceived that the ARCH model is used to overcome the uncertainty of residual risk [29]. The advantage of this approach is that conditional variance, or short-term volatility, is a function of the error on the returns of the past. Bollerslev (1986) noted that the GARCH plan is handled when there is an error variance belonging on the squared error terms pending the last period of the data set [6].

\section{Results and Discussion}

Several of the indexes in the interval 2017 to 2020 show a significant probability value at $\alpha=4 \%$, indicating the existence of a market anomaly month of the year effect. In the period 2017 to 2020, the effect on several indexes is seen regarding March, July, August, September and October. The outcome of this research is the November effect on the NIKKEI 225 index. The month of the year result adumbrations that, per the correct plan of financing with relation to time, money principals, financial solicitors and financiers can obtain benefit of this sample.

Table 1. The Existence of the Month of the Year Effect from 2017 to 2020.

\begin{tabular}{|c|c|c|c|c|c|c|c|}
\hline Index & Method & Jan & Feb & Mar & Apr & May & Jun \\
\hline \multirow{2}{*}{ BISNIS27 } & OLS & 0.003 & 0.0068 & 0.0070 & -0.0016 & -0.0039 & 0.0016 \\
\hline & $\operatorname{GARCH}(1,1)$ & 0.0075 & 0.0080 & 0.0076 & -0.0045 & -0.0056 & 0.0047 \\
\hline \multirow{2}{*}{ JKSE } & OLS & 0.0037 & 0.0061 & 0.0078 & 0.0013 & -0.0031 & 0.0001 \\
\hline & GARCH $(1,1)$ & 0.0037 & 0.0061 & 0.0078 & 0.0013 & -0.0031 & 0.0001 \\
\hline \multirow{2}{*}{ KOMPAS100 } & OLS & 0.0038 & 0.0069 & 0.0075 & -0.0001 & -0.0039 & 0.0000 \\
\hline & $\operatorname{GARCH}(1,1)$ & 0.0077 & 0.0075 & 0.0067 & -0.0042 & -0.0034 & 0.0028 \\
\hline LQ45 & OLS & 0.0043 & 0.0067 & 0.0074 & -0.0003 & -0.003 & 0.0011 \\
\hline \multirow{2}{*}{ PEFINDO2 5} & OLS & 0.003 & 0.0069 & 0.0105 & 0.0032 & 0.0011 & -0.0028 \\
\hline & GARCH $(1,1)$ & 0.0063 & 0.008 & 0.0102 & 0.0031 & -0.0007 & 0.0037 \\
\hline SRI & OLS & 0.004 & 0.0069 & 0.0084 & -0.0004 & -0.0033 & 0.0022 \\
\hline KEHATI & GARCH $(1,1)$ & 0.0081 & 0.0076 & 0.0077 & -0.0042 & -0.0042 & 0.0053 \\
\hline \multirow{2}{*}{ CAC40 } & OLS & 0.0006 & 0.0071 & 0.0018 & -0.001 & -0.0073 & -0.0002 \\
\hline & $\operatorname{GARCH}(1,1)$ & 0.0017 & 0.006 & 0.0023 & 0.0025 & -0.0049 & -0.0003 \\
\hline DAX & OLS & 0.0017 & 0.0062 & 0.0042 & 0.0000 & -0.0046 & -0.0012 \\
\hline \multirow{2}{*}{ FTSE100 } & OLS & -0.0006 & 0.0085 & -0.0019 & 0.0019 & -0.0065 & 0.0006 \\
\hline & GARCH $(1,1)$ & -0.0006 & 0.0085 & -0.0019 & 0.0019 & -0.0065 & 0.0006 \\
\hline \multirow{2}{*}{ IBEX35 } & OLS & -0.0039 & 0.0023 & 0.0000 & -0.0031 & -0.0107 & -0.0005 \\
\hline & GARCH $(1,1)$ & -0.0024 & 0.0019 & 0.0019 & 0.0004 & -0.0089 & -0.0027 \\
\hline
\end{tabular}

Table 1. Continued.

\begin{tabular}{|c|c|c|c|c|c|c|c|}
\hline Index & Method & Jul & Aug & Sep & Oct & Nov & Dec \\
\hline \multirow{2}{*}{ BISNIS27 } & OLS & 0.0070 & -0.0059 & 0.0018 & 0.0058 & -0.0011 & 0.0034 \\
\hline & GARCH $(1,1)$ & 0.0067 & -0.0032 & 0.0090 & 0.003 & -0.0040 & 0.001 \\
\hline \multirow{2}{*}{ JKSE } & OLS & 0.0067 & -0.0051 & 0.0021 & 0.0051 & -0.0004 & 0.0027 \\
\hline & GARCH $(1,1)$ & 0.0067 & -0.0051 & 0.0021 & 0.0051 & -0.0004 & 0.0027 \\
\hline \multirow{2}{*}{ KOMPAS100 } & OLS & 0.0062 & -0.0059 & 0.0013 & 0.0055 & -0.0007 & 0.0024 \\
\hline & GARCH $(1,1)$ & 0.0062 & -0.0042 & 0.0086 & 0.0037 & -0.0018 & 0.0003 \\
\hline \multirow{2}{*}{ LQ45 } & OLS & 0.0064 & -0.0053 & 0.002 & 0.006 & -0.001 & 0.0024 \\
\hline & GARCH $(1,1)$ & 0.0058 & -0.0039 & 0.009 & 0.0041 & -0.0022 & 0.0013 \\
\hline \multirow{2}{*}{ PEFINDO2 5} & OLS & 0.0044 & -0.0112 & 0.0009 & 0.0061 & -0.0025 & 0.0045 \\
\hline & GARCH $(1,1)$ & 0.0107 & -0.0091 & -0.0073 & 0.0021 & -0.0011 & 0.0045 \\
\hline SRI & OLS & 0.0088 & -0.0047 & 0.0018 & 0.0049 & -0.002 & 0.0022 \\
\hline KEHATI & GARCH $(1,1)$ & 0.0085 & -0.0031 & 0.0088 & 0.004 & -0.0032 & 0.0022 \\
\hline $\mathrm{CAC} 40$ & OLS & 0.0006 & -0.0035 & 0.0016 & 0.0069 & 0.001 & 0.0022 \\
\hline
\end{tabular}




\begin{tabular}{|c|c|c|c|c|c|c|c|}
\hline Index & Method & Jul & Aug & Sep & Oct & Nov & Dec \\
\hline \multirow{3}{*}{ DAX } & GARCH $(1,1)$ & 0.0044 & -0.002 & 0.0023 & 0.005 & -0.0001 & 0.003 \\
\hline & OLS & -0.0005 & -0.0067 & 0.0031 & 0.0109 & 0.0066 & 0.001 \\
\hline & GARCH $(1,1)$ & 0.0023 & -0.0032 & 0.0041 & 0.0089 & 0.0074 & 0.0022 \\
\hline \multirow{2}{*}{ FTSE100 } & OLS & 0.0017 & -0.0023 & 0.0000 & 0.0057 & -0.0005 & 0.0037 \\
\hline & GARCH $(1,1)$ & 0.0017 & -0.0023 & 0.0000 & 0.0057 & -0.0005 & 0.0037 \\
\hline \multirow{2}{*}{ IBEX35 } & OLS & -0.0007 & -0.0015 & 0.0069 & 0.0038 & -0.0019 & 0.002 \\
\hline & GARCH $(1,1)$ & 0.0028 & -0.0024 & 0.0056 & 0.0043 & -0.0027 & 0.0026 \\
\hline
\end{tabular}

In the entirely duration and the sub-period of 2017 to 2020 , the September result is realized in all Iranian indexes. This remedy that topics are changing Iran's capital market in this month likely for the Islamic holy day of 'Eid happened in September in the study period. There is the probability that 'Eid affected the Iranian capital market in September for the vast feck of the Iranian population is Islamic. thus, this celebration results the Iranian capital market but not the world's major capital markets in the research conclusion. moreover, in the sub-period 2017 to 2020, the outcome of April on almost all indexes of Iran can be ascribed to the celebration, or birthday, which befalls in April.

\section{Conclusions and Recommendations}

The main conclusions of the present study can be summarized as follows:

The outcome indicates the phenomenon of the month of the year effect by consuming the GARCH with Iranian indexes in the period 2017 to 2020 .

There were no phenomena as to the month of the year and the sub-period effect by using the OLS model.

\section{References}

[1] Arnold, V., Bedard, J. C., Phillips, J. R., and Sutton, S. G. 2012. The impact of tagging qualitative financial information on investor decision making: Implications for XBRL.

[2] International Journal of Accounting Information Systems, 13 (1), 2-20.

[3] Bekaert, G. and Hodrick, R. 2017. International financial management. Cambridge University Press.

[4] Bhuyan, R. 2018. Investments and Security Analysis. Finance.

[5] Bodie, Z., Kane, A. and Marcus, A. J. 2012. Essentials of Investments 9th Edition. McGrawHill.

[6] Bollerslev, T. 1986. Generalized autoregressive conditional heteroskedasticity. Journal of Econometrics, 31 (3), 307-327.

[7] Chandra, P. 2017. Investment analysis and portfolio management. McGraw-Hill Education.

[8] Chatfield, C. 2016. The analysis of time series: An introduction. CRC press.

[9] Chen, Q. 2013. Risk and seasonal effects: International evidence. Journal of Chinese Economic and Business Studies, 11 (4), 299-311.

[10] Chia, R. C. J. and Liew, V. K. S. 2012. Month-of-the-Year and
Symmetrical Effects in the Nikkei 225. Journal of Business and Management, 3 (2), 68-72.

[11] Clarke, J., Jandik, T. and Mandelker, G. 2008. The Efficient Markets Hypothesis. African Journal of Business Management, 3 (17), 28-56. http://doi.org/10.1007/BF01539560.

[12] Denisova, P. I., Rukina, N. S., Samoylova, N. K., Takmazyan, S. A. 2017. Financial.

[13] Instruments of the Socially Responsible Economy. European Research Studies Journal, 20 (1), 284-293.

[14] Fama, E. F. 1960. Efficient market hypothesis. Ph. D. dissertation, University of Chicago, Graduate School of Business.

[15] Fama, E. F. 1998. Market efficiency, long-term returns, and behavioral finance. Journal of Financial Economics, 49 (3), 283-306.

[16] Floros, C. and Salvador, E. 2014. Calendar anomalies in cash and stock index futures.

[17] International evidence. Economic Modelling, 37, 216-223.

[18] Fryzlewicz, P. and Subba Rao, S. 2014. Multiple-change-point detection for auto-regressive conditional heteroscedastic processes. Journal of the Royal Statistical Society: Series B (Statistical Methodology), 76 (5), 903-924.

[19] Georgantopoulos, A. G., Kenourgios, D. F. and Tsamis, A. D. 2011. Calendar anomalies in emerging Balkan equity markets. International Economics and Finance Journal, 6 (1), 67-82.

[20] Hawaldar, I. T., Shakila, B. and Pinto, P. 2017. Empirical Testing of Month of the Year Effect on Selected Commercial Banks and Services Sector Companies Listed on Bahrain Bourse. International Journal of Economics and Financial Issues, 7 (2), 426436.

[21] Jahfer, A. and Inoue, T. 2014. Financial development, foreign direct investment and economic growth in Sri Lanka. International Journal of Economic Policy in Emerging Economies, 7 (1), 77-93.

[22] Jain, N. 2017. Illusion or Reality: Testing the Day-of-the-Week and Month-of-the-Year Effect for Indian Stock Market. Asian Journal of Research in Banking and Finance, 7 (4), 75-84.

[23] Jamróz Pawełand Koronkiewicz, G. 2014. The Occurrence of the Day-of-the-Week Effects on Polish and Major World Stock Markets. Studies in Logic, Grammar and Rhetoric, 37 (1), 71-88.

[24] Jassal, T. and Dhiman, B. 2015. Heterogeneous Evidence: An Analysis of Monthly Anomaly. International Journal of Applied Business and Economic Research, 13 (3), 1377-1389.

[25] Jiang, D. and Autore, D. M. 2014. The Preholiday Corporate Announcement Effect. 
[26] Lee, I. and Lee, K. 2015. The Internet of Things (IoT): Applications, investments, and challenges for enterprises. Business Horizons, 58 (4), 431-440.

[27] Lopez Bernal, J. A., Gasparrini, A., Artundo, C. M. and McKee, M. 2013. The effect of the late 2000s financial crisis on suicides in Spain: an interrupted time-series analysis. The European Journal of Public Health, 23 (5), 732-736.

[28] Moskowitz, T. J., Ooi, Y. H. and Pedersen, L. H. 2012. Time series momentum. Journal of Financial Economics, 104 (2), 228-250.

[29] Nachrowi, N. D. and Usman, H. 2006. Econometrics For Economic and Financial Analysis. Issuing FEUI.

[30] Onoh, J. O. and Ndu-Okereke, O. E. 2016. Day of the Week Effect: Evidence from the Nigerian Stock Exchange. International Journal of Banking and Finance Researc, 2 (3), $76-90$

[31] Piketty, T. 2015. About capital in the twenty-first century. American Economic Review, 105 (5), 48-53.

[32] Rathinasamy, R. S. and Mantripragada, K. G. 1996. The January size effect revisited: is it a case of risk mismeasurement? Journal of Financial and Strategic Decisions, 9 (3), 9-14.

[33] Reilly, F. K. and Brown, K. C. 2002. Investment analysis and portfolio management.

[34] Schwert, G. W. 2003. Anomalies and market efficiency. In Handbook of the Economics of Finance, 1, 939-974.

[35] Sharpe, W. F., Alexander, G. J. and Bailey, J. V. 1999. Investments (International Edition). Prentice Hall, Inc. New Jersey.
[36] Thalassinos, I. E., Pintea, M. and Ratiu, I. P. 2015. The Recent Financial Crisis and Its Impact on the Performance Indexes of Selected Countries during the Crisis Period: A Reply.

[37] International Journal of Economics and Business Administration, 3 (1), 3-20.

[38] Thalassinos, I. E., Hanias, P. M., Curtis, G. P. and Thalassinos, E. J. 2013. Forecasting financial indices: The Baltic Dry Indices. Marine Navigation and Safety of Sea Transportation: STCW, Maritime Education and Training (MET), Human Resources and Crew Manning, Maritime Policy, Logistics and Economic Matters; Code 97318, 283-290, ISBN: 978-113800104-6.

[39] Thalassinos, I. E., Hanias, P. M. and Curtis, G. P. 2012. Time series prediction with neural networks for the Athens Stock Exchange indicator. European Research Studies Journal, 15 (2), 23-31.

[40] Tong, W. H. S. 1992. An analysis of the January effect of United States, Taiwan and South Korean stock returns. Asia Pacific Journal of Management, 9 (2), 189-207.

[41] Wei, W. W. S. 2006. Time series analysis. In the Oxford Handbook of Quantitative Methods in Psychology, Vol. 2.

[42] Wong, W. K., Agarwal, A. and Wong, N. T. 2006. The disappearing calendar anomalies in the Singapore stock market The Lahore Journal of Economics, 11 (2), 123-139.

[43] Zhang, J., Lai, Y. and Lin, J. 2017. The day-of-the-Week effects of stock markets in different countries. Finance Research Letters, 20, 47-62. 